Jurnal PRAXIS | Vol. 3 | No. 1 | September 2020

\title{
Deteksi Dini Kesehatan Mental Akibat Pandemi Covid-19 Pada Unnes Sex Care Community Melalui Metode Self Reporting Questionnaire
}

\author{
Muhammad Iqbal ${ }^{1}$; Lutfiyah Rizqulloh ${ }^{2}$ \\ Universitas Dian Nuswantoro ${ }^{1}$; Universitas Kusuma Husada Surakarta ${ }^{2}$ \\ email: muhammiq@gmail.com ${ }^{1}$; lutfiyah.rizqulloh@gmail.com²
}

\begin{abstract}
The number of COVID-19 sufferers who continue to crawl up in various countries including Indonesia illustrates how quickly the virus spreads and moves, in Indonesia itself until July 2020 the number of positive COVID-19 paisers reached 88,214 people and 4,239 people were reported dead. The COVID-19 pandemic does not only affect physical health, weakening the economy and limiting individual or group interactions are also a pandemic effect that will suppress one's mental health. Adolescent age group is the age group that has the most weight burden compared to adults and children, this is because adolescence is a transition period in which changes in anatomy, physiology, intellectual, emotional, to interaction with the social environment. This type of research is descriptive quantitative research. The sampling method used in this study is total sampling about 40 people who are members of the Unnes Sex Care Community Student Activity Unit Semarang State University in the 2019-2020 period. In the last 30 days as many as $63.6 \%$ of the total respondents indicated experiencing mental health problems, $59 \%$ felt tense, anxious or $50 \%$ found it difficult to sleep, $50 \%$ found it difficult to think clearly, 50\% felt tired all the time and $9 \%$ of the total respondents have thoughts to end their lives.
\end{abstract}

Keywords : Mental Health, Youth, COVID-19

\begin{abstract}
Abstrak
Jumlah penderita COVID-19 yang terus merangkak naik di berbagai negara termasuk Indonesia menggambarkan betapa cepatnya virus tersebut menyebar dan berpindah, di Indonesia sendiri hingga bulan Juli 2020 jumlah paisen positif COVID-19 mencapai 88.214 orang dan 4.239 orang dilaporkan meninggal. Pandemi COVID-19 tidak hanya berdampak kepada kesehatan secara fisik saja, melemahnya ekonomi dan pembatasan interaksi secara individul maupun kelompok juga merupakan dampak pandemi yang akan mempengaruhi kesehatan mental seseorang. Kelompok usia remaja merupakan kelompok usia yang memiliki beban paling berat dibandingkan dengan usia dewasa dan anak-anak, hal ini dikarenakan masa remaja merupakan masa transisi dimana perubahan secara anatomi tubuh, fisiologi, intelektual, emosional, hingga interaksi dengan lingkungan sosialnya. Jenis penelitian yang dilakukan merupakan penelitian kuantitatif deskriptif. Metode pengambilan sampel yang digunakan dalam penelitian ini adalah total sampling berjumlah 44 orang mahasiswa yang tergabung dalam Unit Kegiatan Mahasiswa (UKM) Unnes Sex Care Community Universitas Negeri Semarang tahun periode 2019-2020. Dalam 30 hari terakhir sebanyak $63,6 \%$ dari total responden terindikasi mengalami permasalahan kesehatan secara mental, 59\% merasa tegang, cemas atau 50\% merasa sulit untuk tidur, 50\% merasa sulit untuk berfikir jernih, 50\% merasa lelah sepanjang waktu dan $9 \%$ dari total responden memiliki pemikiran untuk mengakhiri hidupnya
\end{abstract}

Kata Kunci : Kesehatan Mental, Remaja, COVID-19 


\section{PENDAHULUAN}

WHO China Country Office pada akhir Bulan Desember 2019 melaporkan adanya kasus pneumonia dengan etiologi yang tidak diketahui. Pada Bulan Januari 2020 China menyampaikan jika kasus pneumonia dengan etiologi yang tidak diketahui yang ditemukan di Kota Wuhan, Provinsi Hube dinamakan coronavirus disease (COVID-19) dan disebabkan oleh virus jenis baru bernama SARS-CoV-2. Awal tahun 2020 coronavirus disease (COVID-19) ditetapkan menjadi kedaruratan kesehatan masyarakat yang meresahkan dunia oleh WHO mengingat penyebaran dari virus tersebut yang begitu cepat (Kementerian Kesehatan RI, 2020). Jumlah penderita COVID-19 yang terus merangkak naik di berbagai negara termasuk Indonesia menggambarkan betapa cepatnya virus tersebut menyebar dan berpindah, di Indonesia sendiri hingga bulan Juli 2020 jumlah paisen positif COVID-19 mencapai 88.214 orang dan 4.239 orang dilaporkan meninggal (Gugus Tugas Percepatan Penanganan COVID-19, 2020).

Wabah infeksi virus coronavirus COVID-19 antara manusia di Wuhan (Cina) dan penyebarannya di seluruh dunia sangat berdampak pada kesehatan global dan kesehatan mental. Pandemi Covid-19 memiliki dampak secara global kesehatan mental seperti stres, kecemasan, gejala depresi, insomnia, penolakan, kemarahan dan ketakutan secara global (Torales, O'Higgins, Castaldelli-Maia, \& Ventriglio, 2020). Trauma emosional yang mendalam dalam masyarakat yang diliputi oleh bencana manusia berskala besar, seperti, penyakit pandemi global, bencana alam, tragedi buatan manusia, konflik perang, krisis sosial, dapat menyebabkan gangguan besar terkait stres. Pandemi coronavirus global yang sedang berlangsung memicu hal itu terjadi.
Survey yang dilakukan oleh Kaiser Family Foundation yang dilakukan di Amerika Seriklat. Amerika Serikat merupakan negara yang berada di urutan pertama dengan jumlah kasus Covid-19 terbanyak di dunia. Berdasaran informasi yang tercatat pada laman http://worldometers.info , di Amerika Serikat ada sebanyak 644.089 kasus Covid19 per 16 April 2020 (Worldometers, 2020). Hasil survey menunjukkan bahwa hampir setengah dari orang-orang di AS merasakan krisis COVID-19 yang mana merusak kesehatan mental mereka. Survei yang dilakukan pada 25 hingga 30 Maret 2020 menemukan hasil bahwa $45 \%$ orang dewasa mengatakan pandemi COVID-19 telah memengaruhi kesehatan mental mereka, dan 19\% mengatakan memiliki dampak besar terhadap kesehatan mentalnya (Kaiser Family Foundation, 2020).

Menurut World Health Organization (WHO) (2019), stres yang muncul selama masa pandemi COVID-19 dapat berupa: (a). Ketakutan dan kecemasan mengenai kesehatan diri maupun kesehatan orang lain yang disayangi (b). Perubahan pola tidur dan/atau pola makan (c). Sulit tidur dan konsentrasi (d). Memperparah kondisi fisik seseorang yang memang memiliki riwayat penyakit kronis dan/atau gangguan psikologis. Menggunakan obat-obatan (drugs) (World Health Organisation (WHO), 2019). Remaja yang sejatinya merupakan kelompok usia paling rentan akan stress dan kecemasan kini dihadapkan kepada sebuah polemik baru akibat wabah COVID-19 yang akan semakin meningkatkan resiko terjadinya stress dan kecemasan. Kegiatan yang biasanya dapat mereka lakukan dengan wajar kini menjadi terbatas, akses sosial kepada individu dan komunitas juga tidak dapat mereka lakukan seperti biasanya, hal inilah yang dapat menjadi tekanan-tekanan baru kepada kelompok rentan ini selama 
Jurnal PRAXIS | Vol. 3 | No. 1 | Th. 2020

menghadapi wabah COVID-19.

Deteksi dini pada remaja mengenai kesehatan mental dengan menggunakan metode Self Reporting Questionnaire (SRQ) merupakan kuesioner yang sudah valid dan reliabel untuk melakukan skrining gangguan psikiatri dan keperluan penelitian terkait ganguan psikiatri. SRQ dirancang dan dikembangkan oleh World Health Organization (WHO) dan sudah digunakan untuk menilai dan melihat kesehatan jiwa penduduk Indonesia melalui kegiatan Riskesdas (Riset Kesehatan Dasar) pada tahun 2007 (Idaiani, 2009).

\section{METODOLOGI PENELITIAN}

Jenis penelitian yang dilakukan merupakan penelitian kuantitatif deskriptif. Informan utama dalam penelitian ini adalah seluruh mahasiswa yang tergabung dalam Unit Kegiatan Mahasiswa (UKM) Unnes Sex Care Community Universitas Negeri Semarang tahun periode 2019-2020. Metode pengambilan sampel yang digunakan dalam penelitian ini adalah total sampling, yang terdiri dari seluruh anggota UKM Unnes Sex Care Community Universitas Negeri Semarang tahun periode 2019-2020 sebanyak 44 orang. Pengambilan data dilakukan pada bulan Juni-Juli Tahun 2020.

\section{HASIL PENELITIAN DAN PEMBAHASAN}

Self Reporting Questionnaire (SRQ) merupakan kuesioner yang sudah valid dan reliabel untuk melakukan skrining gangguan psikiatri. SRQ merupakan kuesioner yang terdiri dari 20 butir pertanyaan yang berhubungan dengan nyeri tertentu serta masalah yang mungkin mengganggu seseorang selama 30 hari. Responden akan menjawab "Ya" apabila pertanyaan yang ada dalam kuesioner sesuai dengan apa yang dialaminya dalam 30 hari terakhir dan menjawab "Tidak" jika responden merasa dalam 30 hari terakhir tidak mengami kejadian yang ada dalam kuesioner. Menurut Balitbang Kemenkes RI apabila sesorang menjawab "Ya" sebanyak 6 kali atau lebih dari total 20 pertanyaan yang tersedia, maka orang tersebut memiliki indikasi permasalahan kesehatan mental.

Bedasarkan hasil kuesioner yang telah disebar kepada 44 orang responden, didapatkan hasil sebagai berikut :

Tabel 1

Hasil Deteksi Dini Kesehatan Mental Menggunakan metode Self Reporting Questionnaire

\begin{tabular}{cccc}
\hline & $\begin{array}{c}\text { Menjawab } \\
\text { Ya }\end{array}$ & $\begin{array}{c}\text { Menjawab } \\
\text { Tidak }\end{array}$ & Total \\
\hline Jumlah & 28 & 16 & 44 \\
\hline Prosentase & $63,6 \%$ & $36,4 \%$ & $100 \%$ \\
\hline
\end{tabular}

Hasil menunjukan jika $63,6 \%$ responden terindikasi mengalami permasalahan kesehatan mental akibat pandemi COVID19. Dilihat dari 20 butir pertanyaan dijawab oleh responden, dapat dilihat adanya kondisi atau permasalahan yang paling sering muncul yaitu :

\section{Merasa Tegang, Cemas atau Kuatir}

Selama waktu 30 hari terakhir perasaan tegang, cemas atau khawatir menjadi kondisi paling sering yang dialami oleh responden

Tabel 2

Jumlah Responden yang Merasa Tegang, Cemas Atau Kuatir

\begin{tabular}{cccc}
\hline & $\begin{array}{c}\text { Menjawab } \\
\text { Ya }\end{array}$ & $\begin{array}{c}\text { Menjawab } \\
\text { Tidak }\end{array}$ & Total \\
\hline Jumlah & 26 & 18 & 44 \\
\hline Prosentase & $59 \%$ & $41 \%$ & $100 \%$ \\
\hline
\end{tabular}

Berdasarkan tabel 2 dari 44 responden yang menjawab merasa tegang, 
Jurnal PRAXIS | Vol. 3 | No. 1 | Th. 2020

cemas atau khawatir selama 30 hari terakhir atau pada saat wabah COVID-19 berlangsung sebanyak 26 orang (59\%).

\section{Merasa Sulit untuk Tidur}

Sulit untuk tidur merupakan kondisi yang dirasa sering dialami oleh responden dalam 30 hari terakhir.

Tabel 3

Jumlah Responden yang Merasa Sulit Untuk Tidur

\begin{tabular}{cccc}
\hline & $\begin{array}{c}\text { Menjawab } \\
\text { Ya }\end{array}$ & $\begin{array}{c}\text { Menjawab } \\
\text { Tidak }\end{array}$ & Total \\
\hline Jumlah & 22 & 22 & 44 \\
\hline Prosentase & $50 \%$ & $50 \%$ & $100 \%$ \\
\hline
\end{tabular}

Berdasarkan tabel 3 dari 44 responden yang menjawab merasa sulit tidur selama 30 hari terakhir atau pada saat wabah COVID-19 berlangsung sebanyak 22 orang (50\%).

\section{Merasa Sulit untuk berpikir jernih}

Sulit untuk berfikir jernih menjadi kondisi yang cukup banyak dialami oleh responden dalam 30 hari terakhir

\section{Tabel 4}

Jumlah Responden yang Merasa Sulit untuk berfikir jernih

\begin{tabular}{cccc}
\hline & $\begin{array}{c}\text { Menjawab } \\
\text { Ya }\end{array}$ & $\begin{array}{c}\text { Menjawab } \\
\text { Tidak }\end{array}$ & Total \\
\hline Jumlah & 22 & 22 & 44 \\
\hline Prosentase & $50 \%$ & $50 \%$ & $100 \%$ \\
\hline
\end{tabular}

Berdasarkan tabel 4 dari 44 responden yang menjawab merasa sulit untuk berfikir jernih selama 30 hari terakhir atau pada saat wabah COVID-19 berlangsung sebanyak 22 orang $(50 \%)$.

\section{Merasa Lelah Sepanjang Waktu}

Jawaban responden menggambarkan jika rasa lelah sepanjang waktu merupakan salah satu kondisi yang sering dialami dalam 30 hari terakhir
Tabel 5

Jumlah Responden yang Merasa Lelah Sepanjang Waktu

\begin{tabular}{cccc}
\hline & $\begin{array}{c}\text { Menjawab } \\
\text { Ya }\end{array}$ & $\begin{array}{c}\text { Menjawab } \\
\text { Tidak }\end{array}$ & Total \\
\hline Jumlah & 22 & 22 & 44 \\
\hline Prosentase & $50 \%$ & $50 \%$ & $100 \%$ \\
\hline
\end{tabular}

Berdasarkan tabel 5 dari 44 responden yang menjawab merasa lelah sepanjang waktu selama 30 hari terakhir atau pada saat wabah COVID-19 berlangsung sebanyak 22 orang $(50 \%)$.

\section{Mempunyai Pikiran untuk Mengakhiri Hidup}

Jawaban responden terkait memiliki pemikiran untuk mengakhiri hidupnya memang tidak banyak, tetapi hal ini tidak dapat diabaikan, nyatanya kesehatan mental yang terganggu dapat memicu tindakan paling ekstrim salah satunya adalah mengakhiri hidup

Tabel 6

Jumlah Responden yang Mempunyai Pemikiran untuk Mengakhiri Hidup

\begin{tabular}{cccc}
\hline & $\begin{array}{c}\text { Menjawab } \\
\text { Ya }\end{array}$ & $\begin{array}{c}\text { Menjawab } \\
\text { Tidak }\end{array}$ & Total \\
\hline Jumlah & 4 & 40 & 44 \\
\hline Prosentase & $9 \%$ & $91 \%$ & $100 \%$ \\
\hline
\end{tabular}

Dampak pandemi COVID-19 dapat mempengaruhi kesehatan mental hingga berujung kepada pemikiran-pemikiran ekstrim. Sekitar 9\% dari total responden memiliki pemikiran untuk mengakhiri hidupnya.

Berdasarkan hasil penelitian diatas didapat bahwa terdapat adanya indikasi gangguan kesehatan mental pada remaja di masa pandemi Covid-19 dengan menggunakan metode Self Reporting Questionnaire (SRQ). Hasil penelitian deskriptif ini didukung juga oleh hasil survey dari orang-orang di AS yang merasakan krisis COVID-19 merusak 
kesehatan mental mereka. Survei yang dilakukan pada 25 hingga 30 Maret 2020 menemukan hasil bahwa $45 \%$ orang dewasa mengatakan pandemi COVID-19 telah memengaruhi kesehatan mental mereka, dan 19\% mengatakan memiliki dampak besar terhadap kesehatan mentalnya (Kaiser Family Foundation, 2020).

\section{SIMPULAN}

Pandemi COVID-19 faktanya tidak hanya mempengaruhi kesehatan secara fisik, melainkan juga kesehatan secara mental. Bedasarkan hasil penelitian deteksi dini kesehatan mental akibat pandemi COVID-19 pada remaja melalui metode self reporting questionnaire (studi pada organisasi unnes sex care community) didapatkan kesimpulan sebagai berikut:

a. Sebanyak $63,6 \%$ dari total responden terindikasi mengalami permasalahan kesehatan secara mental

b. 26 dari total 44 responden atau $59 \%$ merasa tegang, cemas atau khawatir selama 30 hari terakhir

c. 22 orang dari total 44 responden atau $50 \%$ merasa sulit untuk tidur selama 30 hari terakhir

d. 22 orang dari total 44 responden atau $50 \%$ merasa sulit untuk berfikir jernih selama 30 hari terakhir

e. 22 orang dari total 44 responden atau $50 \%$ merasa lelah sepanjang waktu selama 30 hari terakhir

f. $9 \%$ dari total responden memiliki pemikiran untuk mengakhiri hidupnya

\section{Daftar Pustaka}

Gugus Tugas Percepatan Penanganan COVID-19. (2020). Data Sebaran COVID-19 di Indonesia.

Idaiani, S. (2009). Analisis 20 Butir Pertanyaan Self Reporting Questionnaire pada Masyarakat Indonesia. Pusat Penelitian Dan Pengembangan Bio Medis Dan Farmasi.

Kaiser Family Foundation. (2020). Health Tracking Poll. Henry J Kaiser Family Foundation.

Kementerian Kesehatan RI, (P2P) DJP dan PP. (2020). Pedoman pencegahan dan pengendalian coronavirus disease (covid-19) revisi ke-4. Jakarta: Kementerian Kesehatan.

Torales, J., O’Higgins, M., Castaldelli-Maia, J. M., \& Ventriglio, A. (2020). The Outbreak of COVID-19 Coronavirus and its Impact on Global Mental Health. International Journal of Social Psychiatry, 002076402091521. https://doi.org/10.1177/0020764020915 212

World Health Organisation (WHO). (2019). Mental Health During Covid-19 Pandemic.

Worldometers. (2020). Worldometer COVID-19 Data. 